\title{
ENHANCEMENT OF Spodoptera littoralis (Boisd.) SUSCEPTIBILITY TO NUCLEOPOLYHEDROVIRUS (Spli MNPV) COMBINED WITH INSECT GROWTH REGULATORS (IGR's)
}

(Received: 30.9.2009)

\author{
By \\ A. Thabit*, S. El Salamouny, A. E. Abdel-Aal*, M.A.K. El-Sheikh and S. Elnagar \\ Department of Economic Entomology and Pesticides, Faculty of Agriculture, Cairo University, and \\ *Plant Protection Research Institute, Agricultural Research Center, Ministry of Agriculture, \\ Dokki, Giza, Egypt.
}

\begin{abstract}
Five insect growth regulators (IGR's) were tested to increase the susceptibility of the cotton leaf worm, Spodoptera littoralis (Boisd.) (Lepidoptera: Noctuidae) to its homologous nucleopolyhedrovirus (SpliMNPV). Spodoptera littoralis MNPV was tested alone or in combination with IGR's at LC $_{10}$ level against second instar larvae of the pest. An increased infection rate was detected in the mixture containing SpliMNPV+IGRs in the case of using Chlorfluazuron, Flufenoxuron, Triflumuron, Hexaflumuron or Teflubenzuron at $10 \%$. The $\mathrm{LC}_{50}$ value for the virus alone treatment was $1 \times 10^{7} \mathrm{PIB}$ 's reduced to $4.3 \times 10^{6}, 9.9 \times 10^{4}, 4.9 \times 10^{4}, 3.1 \times 10^{5}$ and $1.69 \times 10^{6}$ PIB's, with the five IGR's, respectively.
\end{abstract}

Key words: insect growth regulators, IGR's, nucleopolyhedrovirus, NPV, Spodoptera littoralis.

\section{INTRODUCTION}

Baculoviruses are promising biocontrol agents in plant protection due to their host specificity, thus safety to the environment. Several studies showed an increase of host susceptibility to virus by using certain additives such as fluorescent brighteners (Shapiro and Dougherty, 1994; and El Salamouny, 2004). The mechanism of increase in the susceptibility by brighteners was confirmed as causing disruption in the midgut defense system in insects (the peritrophic membrane) which lines the midgut (Wang and Granados, 2000). Lepidopteran insects are most susceptible to IGR's that cause molting disturbances (Smagghe et al., 2001; Smagghe and Degheele, 1992 and 1994) and the difference in susceptibility depends on the larval age.

Based on the work published by Arakawa (2002), Flufenoxuron (IGR) promoted infection of the silkworm Bombyx mori $5^{\text {th }}$-instar larvae by $B$. mori nucleopolyhedrovirus (BmNPV) which could be due to interference with chitin synthesis of the peritrophic membrane.

In this study, five insect growth regulators (IGRs) were tested to increase the susceptibility of Spodoptera littoralis to its homologous nucleopolyhedrovirus (SpliMNPV) in order to select the best enhancement effect.

\section{MATERIALS AND METHODS}

\subsection{Test insect}

The cotton leaf worm, Spodoptera littoralis larvae were raised on the semi-synthetic diet of Shorey and Hale (1965). The test insect in all experiments was the $2^{\text {nd }}$ instar larvae.

\subsection{Virus}

The Egyptian isolate of Spodoptera littoralis multiple embedded nucleopolyhedrovirus (Spli MNPV) was used. Virus suspension was prepared in distilled water. Serial viral concentrations ranged from $4.3 \times 10^{4}$ to $10^{7} \mathrm{PIBs} / \mathrm{ml}$ were used to determine the lethal concentrations (LC) values.

\subsection{Insect growth regulators}

Five insect growth regulators (IGR's), were used as synergistic additives to SpliMNPV inocula. The tested additives were Chlorfluazuron (IKI-7899, 10\% EC, Atabron ${ }^{\mathrm{TM}}$ ), Flufenoxuron (10\% EC, Cascade $\left.{ }^{\mathrm{TM}}\right)$, Triflumuron (Systeine, SIR 8514 ${ }^{\mathrm{TM}}$ ), Hexaflumuron (Consult ${ }^{\mathrm{TM}}$ ) and Teflubenzuron (15\% EC, Nomoult $\left.{ }^{\mathrm{TM}}\right)$. All tested IGR's were freshly prepared in distilled water before each test. The concentrations were adjusted as part per million (ppm). To determine the LC values, serial concentrations ranged from 0.0078 to $8 \mathrm{ppm}$ were used.

\subsection{Virus purification}

To get enough virus inocula for the experiments, 
propagation of SpliMNPV in the third instar $S$. littoralis larvae was done. The obtained dead larvae were homogenized in distilled water, then the suspension was filtered and centrifuged at 600 rpm for 10 minutes. The collected supernatant was centrifuged at $4000 \mathrm{rpm}$ for 15 minutes and PIB's particles were separated as a supernatent. The final stock suspension of approximately 2.8 $\times 10^{9} \mathrm{PIB}$ 's $/ \mathrm{ml}$, was stored frozen until usage.

\subsection{Bioassay}

The diet bioassay technique (Huber, 1986) was used for the second instar test larvae. Fifty $\mathrm{ml}$ of diet (synthetic diet without the
Also, the means were compared by using Duncan's multiple range test (Duncan, 1955) Mortality-concentration response was estimated according to Finney (1971).

\section{RESULTS}

Data presented in Table (1) and illustrated in Fig. (1), show the susceptibility of the $2^{\text {nd }}$ instar larvae of $S$. littoralis towards the tested IGRs. Based on the obtained $\mathrm{LC}_{50}$ values, the toxicity of the IGR's ranked in the following descending order: Hexaflumuron, Chlorfluazuron, Flufenoxuron, Teflubenzuron and Triflumuron.

Table (1): $\mathrm{LC}_{10}$ and $\mathrm{LC}_{50}$ of different insect growth regulators (IGRs) and the SpliMNPV, each tested separately.

\begin{tabular}{|l|c|c|c|}
\hline \multicolumn{1}{|c|}{ Tested material } & LC $_{\mathbf{1 0}}$ & $\mathbf{L C}_{\mathbf{5 0}}$ & Toxicity line Slope $\mathbf{\pm}$ S.E. \\
\hline Hexaflumuron $(\mathrm{ppm})$ & 0.0017 & 0.0039 & $3.638 \pm 0.915$ \\
\hline Chlorfluazuron $(\mathrm{ppm})$ & 0.0636 & 0.1179 & $4.22 \pm 0.088$ \\
\hline Flufenoxuron $(\mathrm{ppm})$ & 0.0571 & 0.140 & $3.28 \pm 0.180$ \\
\hline Teflubenzuron $(\mathrm{ppm})$ & 0.0877 & 0.171 & $4.425 \pm 0.915$ \\
\hline Triflumurone $(\mathrm{ppm})$ & 1.431 & 3.6002 & $3.251 \pm 0.212$ \\
\hline SpliMNPV(PIB's/ml) & $4.5 \times 10^{4}$ & $1.07 \times 10^{7}$ & $0.82 \pm 0.2$ \\
\hline
\end{tabular}

formaldehyde) were poured in a special bioassay plate measuring $14 \times 7 \times 2 \mathrm{~cm}$, contains fifty cells. A standard volume suspension of $2 \mathrm{ml}$ per plate was pipetted evenly on the surface of $50 \mathrm{ml}$ of the diet, and left to air dry. One second instar larva was placed into each cell, and each plate was covered with two layers of tissue paper and a $14.5 \times 7.5 \mathrm{~cm}$ glass cover fixed with rubber bands. Three replicates were tested in each treatment and all incubated at $25 \pm 2{ }^{\circ} \dot{\mathrm{C}}$ and 60 $70^{\circ} \mathrm{RH}$ for 14 days during which mortality was daily recorded.

\subsection{Statistical analysis}

Analysis of variance (ANOVA) of the obtained data was performed by using COSTAT program, which runs under Microsoft Windows.
The results presented in Table (2) indicate that mixing SpliMNPV with IGR's reduced the $\mathrm{LC}_{50}$ of SpliMNPV from $1 \times 10^{7} \mathrm{PIB}$ 's $/ \mathrm{ml}$ to $4.3 \times 10^{6}, 9.9 \times 10^{4}, 4.9 \times 10^{4}, 3.1 \times 10^{5}$ or $1.69 \times 10^{6}$ PIB's/ml when mixed with Chlorfluazuron, Flufenoxuron, Triflumuron, Hexaflumuron or Teflubenzuron, respectively.

Initial tests showed no, enhancement effect when Spli MNPV and IGR's were mixed each at the level of $\mathrm{LC}_{10}$. When the five tested IGR compounds were mixed at the $\mathrm{LC}_{10}$ level with the virus at $\mathrm{LC}_{50}$ level $\left(1 \times 10^{7} \mathrm{PIB} / \mathrm{s} / \mathrm{ml}\right)$ enhancement effect on larval mortality could be detected. The average of mortality in the virus alone treatment $(25.33 \%)$ increased to $52.02,75.33,57.14$, 70.94 and $86.23 \%$,by adding the IGR compounds

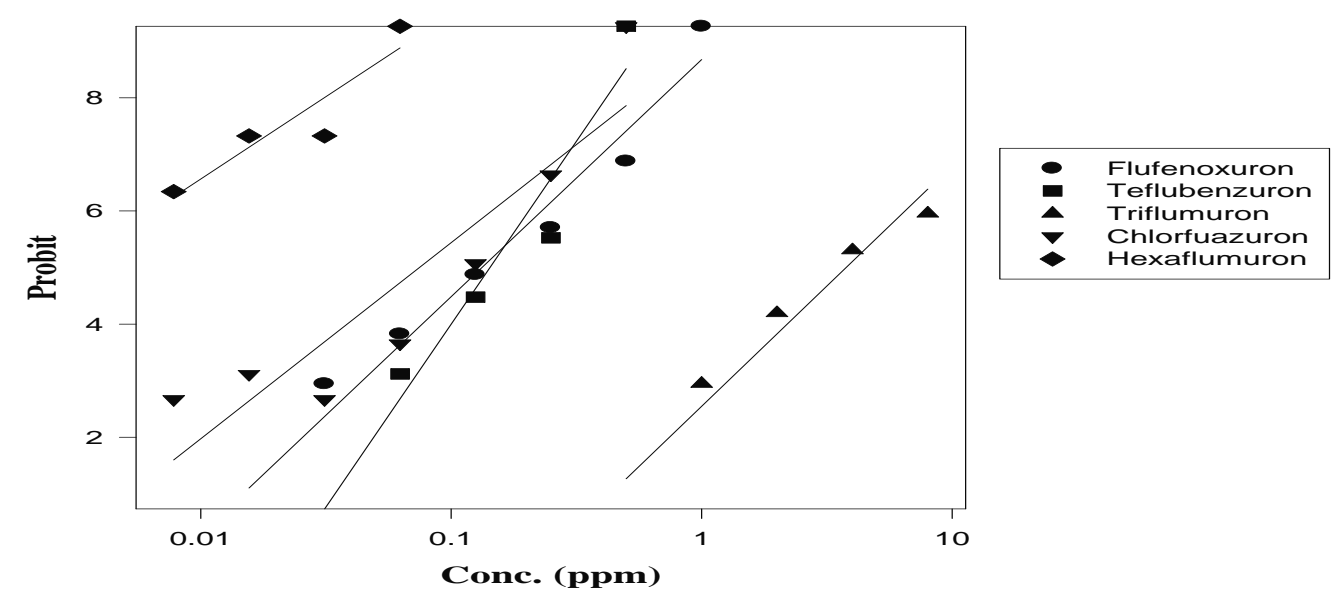

Fig. (1): Toxicity lines of insect growth regulators on Spodoptera littoralis second instar larvae. 
Table (2): Larval mortality (\%) at the different SpliMNPV concentrations mixed with the insect growth regulators (IGRs) at $\mathbf{L C}_{10}$.

\begin{tabular}{|l|c|c|c|c|c|}
\hline \multirow{2}{*}{ IGRs } & \multicolumn{3}{|c|}{$\begin{array}{c}\text { Larval mortalities (\%) at LC } \\
\text { with of IGRs mixed }\end{array}$} & \multirow{2}{*}{$\begin{array}{c}\text { Resulted LC } \\
\text { value }\end{array}$} \\
\cline { 2 - 5 } & $\mathbf{1 0}^{\mathbf{7}}$ & $\mathbf{1 0}^{\mathbf{6}}$ & $\mathbf{1 0}^{\mathbf{5}}$ & $\mathbf{4 . 3 \times 1 0 ^ { 4 }}$ & \\
\hline Chlorfluazuron & 57.1 & 41.6 & 6 & 6.25 & $4.30 \times 10^{6}$ \\
\hline Flufenoxuron & 72 & 48.9 & 16 & 2 & $9.90 \times 10^{4}$ \\
\hline Triflumuron & 75.5 & 64 & 62 & 36 & $4.90 \times 10^{4}$ \\
\hline Hexaflumron & 84 & 78 & 20 & 18 & $3.10 \times 10^{5}$ \\
\hline Teflubenzron & 68 & 46.9 & 16 & 18 & $1.69 \times 10^{6}$ \\
\hline Virus alone & 51.1 & 29.7 & 18.3 & 4.4 & $1.00 \times 10^{7}$ \\
\hline
\end{tabular}

Chlorfluazuron, Triflumurone, Hexaflumuron, Teflubenzuron or Flufenoxuron, respectively (Table, 3 and Fig., 2). A decrease in the lethal time needed $\left(\mathrm{LT}_{50}\right.$ value) for viral mortality in virus alone treatment varied from 8.8 days to $8.54,8.278,7.242,8.41$ or 8.21 days was achieved by adding the above-mentioned IGR the products, respectively. However, in the case of total mortality, a significant decrease in the $\mathrm{LT}_{50}$ value was detected (Table, 3 and Fig., 3)

Table (3): Viral mortality (\%) and $\mathbf{L} \mathbf{T}_{50}$ value (Days) among Spodoptera littoralis test larvae resulting from mixing the five IGR's at $\mathrm{LC}_{10}$ with $\mathrm{SpliMNPV}$ at $\mathrm{LC}_{50}$ level $\left(1 \times 10^{7}\right.$ PIBs/ml).

\begin{tabular}{|l|c|c|}
\hline Treatment & Mortality (\%) & LT $_{50}$ (Days) \\
\hline NPV alone $\left(1 \times 10^{7}\right.$ PIBs/ml) & $\mathbf{2 5 . 3 3}^{\text {f }}$ & $\mathbf{8 . 8}^{\text {a }}$ \\
\hline NPV+Chlorfluazuron & $\mathbf{5 2 . 0 2}^{\text {e }}$ & $\mathbf{8 . 4 9 3}^{\text {a }}$ \\
\hline NPV+ Triflumurone & $\mathbf{7 5 . 3 3}^{\text {b }}$ & $\mathbf{7 . 1 8 7}^{\text {bc }}$ \\
\hline NPV+Hexaflumuron & $\mathbf{5 7 . 1 4}^{\text {d }}$ & $\mathbf{7 . 0 8 4}^{\text {bc }}$ \\
\hline NPV+Teflubenzuron & $\mathbf{7 0 . 9 4}^{\text {c }}$ & $7.865^{\text {ab }}$ \\
\hline NPV+Flufenoxuron & $\mathbf{8 6 . 2 3}^{\text {a }}$ & $\mathbf{6 . 1 2 1}^{\text {c }}$ \\
\hline F value & $\mathbf{4 7 4 . 4 9}^{* * *}$ & $\mathbf{8 . 7 8 0}^{* *}$ \\
\hline L.S.D & $\mathbf{3 . 0 3 9}$ & $\mathbf{1 . 0 3 2 7 2}$ \\
\hline
\end{tabular}

Means with the same letter are not significantly different $(\mathrm{p}<0.05)$.

all dead larvae were individually smear tested to confirm SpliMNPV causal agent

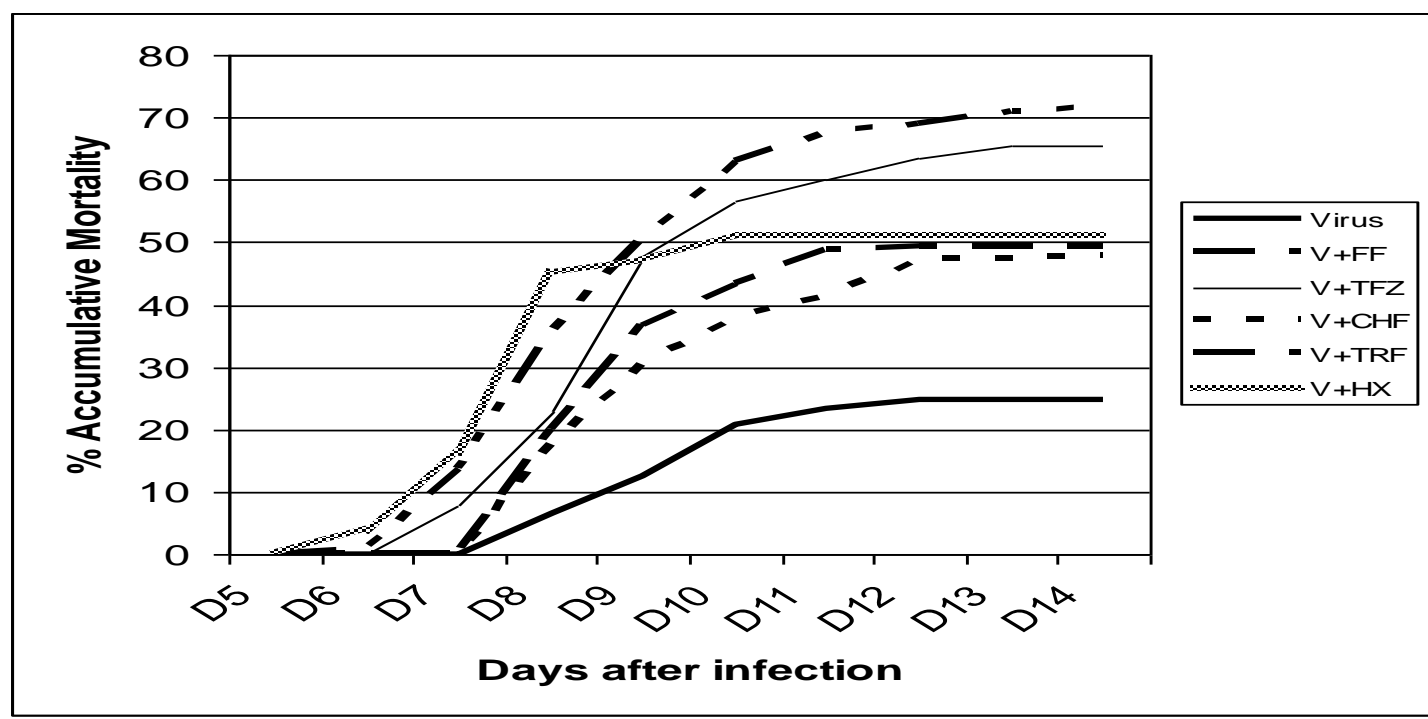

Fig. (2). Accumulated viral mortality of Spodoptera littoralis larvae treated with $S p l i M N P V$ at $\mathrm{LC}_{50}\left(\mathbf{1 0}^{7} \mathrm{PIBs} / \mathrm{ml}\right)$ alone or mixed with insect growth regulators. $\mathrm{V}=$ Virus $\mathrm{FF}=$ Flufenoxuron, TFZ=Teflubenzuron, $\mathrm{CHF}=$ Chlorfluazuron, $\mathrm{TRF}=$ Triflumuron $\mathrm{HX}=$ Hexaflumron . 


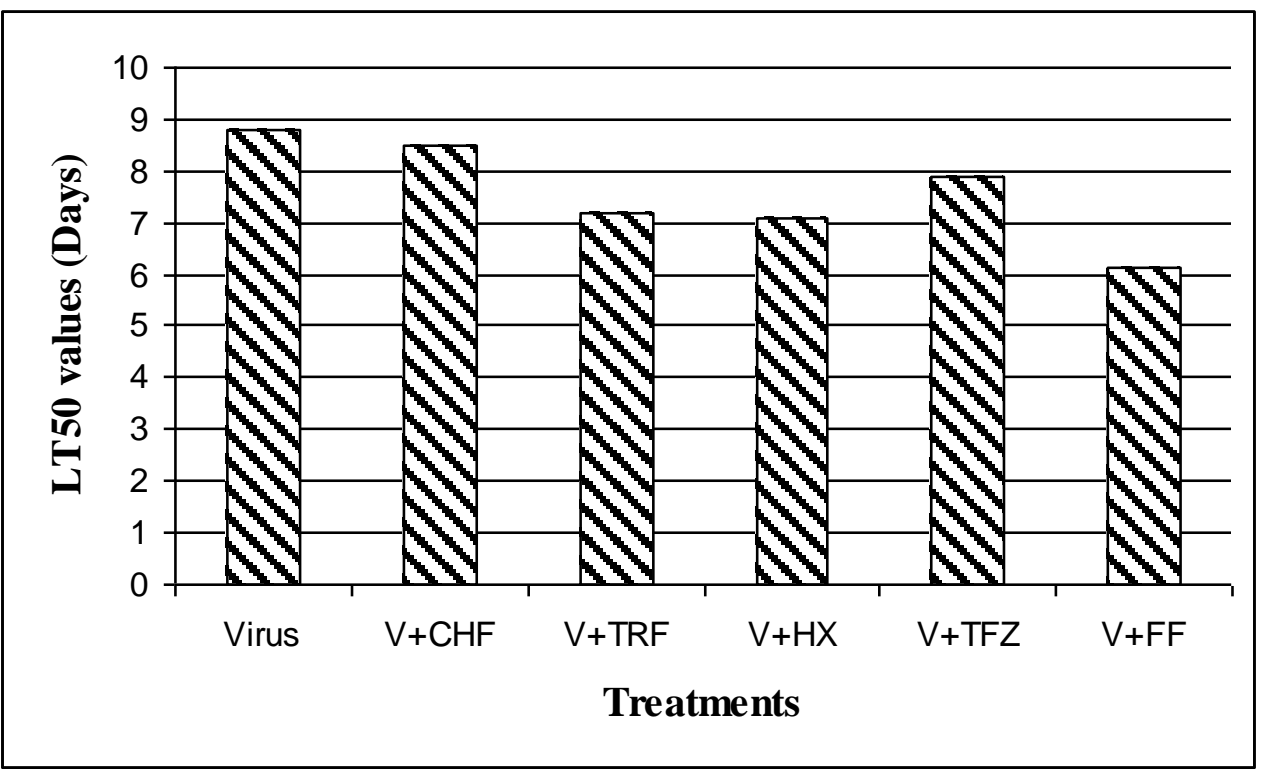

Fig. (3): $\mathrm{LT}_{50}$ values (in days) of viral mortality at $10^{7} \mathrm{PIB}$ 's/ml SpliMNPV either in virus alone treatment, or with IGRs at $\mathrm{LC}_{10}$ :

$\mathrm{V}=$ VirusFF= Flufenoxuron, $\mathrm{TFZ}=$ Teflubenzron, $\mathrm{CHF}=$ Chlorfluazuron, $\mathrm{TRF}=$ Triflumuron, $\mathrm{HX}=$ Hexaflumron

\section{DISCUSSION}

In the present investigation, the mortality response of the larvae caused by the tested IGRs is similar to that found by Abdel Aal (2003) and Ali (2005).

Previous studies showd the mechanism of increasing the susceptibility to NPV in the absence of peritrophic membrane (PM) in tortricid insects (El Salamouny, 2009). The enhancement effect can be explained by damaging the chitin or protein in PM (Shapiro et al., 1987 and Lepore et al., 1996).

The highest rate of enhancement obtained in the case of flufenoxuron was less than that found by Arakawa (2002). The obtained increase in mortality rate could be explained by the role played by IGR in facilitating the virus infection invasion of the midgut.

The results support the possibility of using sublethal IGRs to enhance baculoviruses activity in an Integrated Pest Management Program.

\section{REFERENCES}

Abdel-Aal A. (2003). Effect of Some Insect Growth Regulators on Certain Biological, Biochemical and Histopathological aspects of the Cotton Leafworm, Spodoptera littoralis (Boisd.). (Noctuidae: Lepidoptera). Ph.D. Thesis, Cairo Univ., Egypt. 95-114.
Ali M. A. (2005). Comparative Toxicity of the Ecdysteroid Against Tebufenozide and the Chitin Synthesis Inhibitor Chlorfluazuron to the laboratory stain of Spodoptera littoralis (Boisd.). M.Sc. Thesis, Fac. Agric., Cairo Univ., Egypt. 43-90.

Arakawa T. (2002). Promotion of nucleopolyhedrovirus infection in larvae of the silkworm, Bombyx mori (Lepidoptera: Bombycidae) by flufenoxuron. Appl. Entomol. Zool 37 (3): 393-397.

Duncan D. B. (1955). Multiple range and multiple F-test. Biometrics, 11 (1): 1- 24.

El Salamouny S. (2004). Effect of certain optical brighteners on the susceptibility of Spodoptera littoralis (Boisduval) (Lepidoptera: Noctuidae) to a baculovirus: effect on some biological aspects. J. Agric. Sci. Mansoura Univ., 29(5): 2879-2892.

El Salamouny, S. (2009). Observations on the peritrophic membrane of tortricid and noctuid insects and its role in susceptibility and enhancement. Journal of Agricultural and Urban Entomolology. 24 (4): 195-204.

Finney D. J. (1971). Probit Analysis. $3^{\text {rd }}$ ed., Cambridge Univ., Cambridge, U.K.

Huber J. (1986). Use of baculoviruses in pest mangement programs. In The Biology of Baculoviruses (R. R. Granados and B. 
Federici, Eds.), CRC Press, Boca Raton, FL. $2: 181-202$.

Lepore L. S., Roelvink P. R. and Granados R. R. (1996). Enhancin, the granulosis virus protein that facilitates nucleopolyhedrovirus (NPV) infections, is a metalloprotease. J. Invertebr. Pathol. 68 (2): 131-140.

Shapiro M., Preisler H. K. and Robertson J. L. (1987). Enhancement of baculovirus activity on gypsy moth (Lepidoptera: Lymantriidae) by chitinase. J. Econ. Entomol. 80: 11131116.

Shapiro M. and Dougherty E. M. (1994). Effect of neem extract upon the gypsy moth (Lepidoptera: Lymantriidae) and its nuclear polyhedrosis virus. J. Econ. Entomol. 87:356360.

Shorey H. H. and Hale R. L. (1965). Mass rearing of the larvae of nine noctuid species on a simple artificial medium. J. Econ. Entomol. 58: 522-524.
Smagghe G. and Degheele D. (1992). Effect of RH 5849, the first non steroidal ecdysteroid agonist, on larvae of Spodoptera littoralis (Boisd.) (Lepidoptera: Noctuidae). Archives Insect Biochem. Physiol. 21(2): 119-128.

Smagghe G. and Degheele D. (1994). Action of the non steroidal ecdysteroid mimic RH-5849 on larval development and adult reproduction of insects of different orders. Invertebrate Reproduction \& Development. 25 (3): 227236.

Smagghe G., Carton B., Decombel L. and Tirry L. (2001). Significance of absorption, oxidation, and binding to toxicity of four ecdysone agoinst in multi-resistance cotton leaf worm. Arch. Insect Biochem. Physiol. Zool., 46 (3): 127-39.

Wang P. and Granados R. R. (2000). Calcoflour disrupts the midgut defense system in insects. Insect Biochem. Mol. Biol. 30: 335-339.

$$
\begin{aligned}
& \text { زيادة حساسية دودة ورق القطن للإصابة بفيروس البوليهيدروسز النووى(Spli MNPV) } \\
& \text { بالخلط مع منظمات النمو الحشرية } \\
& \text { آمال ثابت *- سعيد السلاموني ـعزيزة عبد العال * محمد عبد القادر الثيخ - صلاح النجار }
\end{aligned}
$$

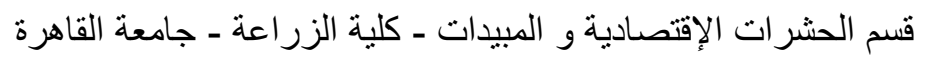

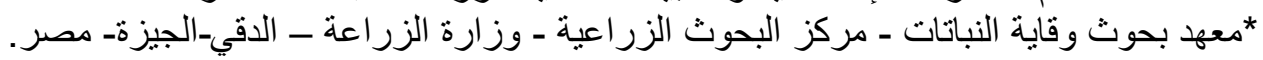

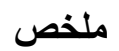

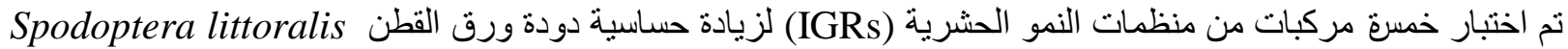

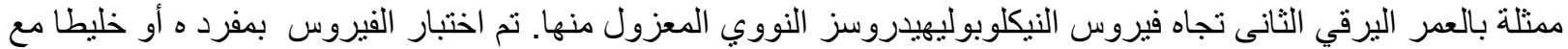

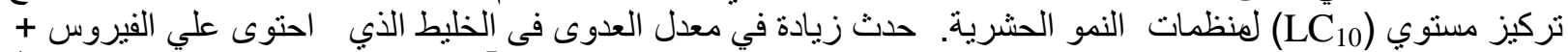

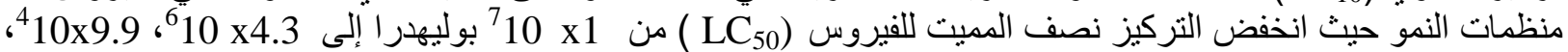

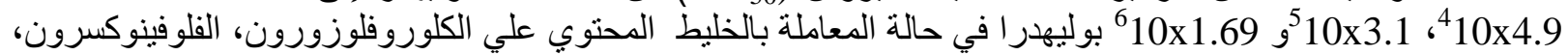

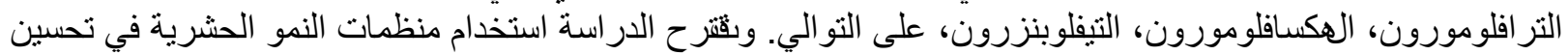

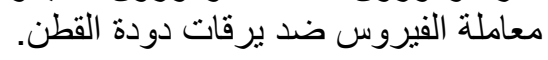

